\title{
ORIGIN OF THE JEZERO V LEDVICAH LAKE; A DEPRESSION IN A GUTTER-SHAPED KARSTIC AQUIFER (JULIAN ALPS, NW SLOVENIA)
}

\author{
NASTANEK JEZERA V LEDVICAH - \\ GLOBEL V ŽLEBU PODOBNEM KRAŠKEM VODONOSNIKU \\ (JULIJSKE ALPE, SZ SLOVENIJA)
}

\author{
Boštjan ROŽIČ ${ }^{1, *}$, Tomislav POPIT ${ }^{1}$, Luka GALE ${ }^{1,2}$, Timotej VERBOVŠEK ${ }^{1}$, Ines VIDMAR ${ }^{1}$, \\ Matej DOLENEC ${ }^{1} \&$ Petra ŽVAB ROŽIČ ${ }^{1}$
}

\begin{abstract}
UDC 556.55:551.44(234.323.6)

Boštjan Rožič, Tomislav Popit, Luka Gale, Timotej Verbovšek, Ines Vidmar, Matej Dolenec \& Petra Žvab Rožič: Origin of the Jezero $v$ Ledvicah lake; a depression in a gutter-shaped karstic aquifer (Julian Alps, NW Slovenia)

The Julian Alps are composed almost exclusively of Triassic to Lower Jurassic carbonates, which results in a karstified high-alpine landscape. In such settings, large water accumulations are not expected and precipitated water drains vertically, gathers in deep, large-scale aquifers, and outflows in large karstic springs located in deeply incised valleys. Some small lakes, however, exist in high alpine areas. Most commonly, they formed above impermeable glacial sediments and are generally characterized by stagnant waters. Jezero $\mathrm{v}$ Ledvicah lake, which is one of the seven lakes in the Triglav Lakes Valley, is an exception, because it shows high subaqueous water inflow and outflow and occurs among highly karstified and permeable carbonates. Combining previous research with our new, detailed geological mapping of the lake surroundings and sedimentary research on the Lower Jurassic strata, we propose a hydrogeological model with the aim of explaining the extraordinary behaviour of the lake. We propose that Jezero v Ledvicah lake: A) is part of the "guttershaped" aquifer with perched groundwater that is situated below the floor of the Triglav Lakes Valley; B) barriers of the aquifer are structural (faults and thrust) and stratigraphic (clay interlayers in Lower Jurassic limestone); C) the lake formed in a structural, hydrogeological and morphological depression within this aquifer; D) the groundwater of the aquifer is recharged not solely from the surface directly above the aquifer
\end{abstract}

\begin{abstract}
Izvleček
UDK 556.55:551.44(234.323.6)

Boštjan Rožič, Tomislav Popit, Luka Gale, Timotej Verbovšek, Ines Vidmar, Matej Dolenec \& Petra Žvab Rožič: Nastanek Jezera $v$ Ledvicah - globel $v$ žlebu podobnem kraškem vodonosniku (Julijske Alpe, SZ Slovenija)

Julijske Alpe skoraj v celoti sestavljajo triasni in jurski karbonati, kar se odraža v morfologiji kraške visokogorske pokrajine. $\mathrm{V}$ tovrstnih razmerah ni pričakovati večjih površinskih pojavov vode, saj padavinska voda pronica vertikalno in se akumulira v obsežnih globokih vodonosnikih, iz teh pa izteka v izdatnih kraških izvirih, ki so v globoko vrezanih dolinah. Kljub temu v alpskem visokogorju obstaja nekaj manjših jezer. Večina jih je nastala nad neprepustnimi ledeniškimi sedimenti in jih lahko opredelimo kot stoječe vode. Jezero v Ledvicah, ki je eno izmed sedmih jezer v dolini Triglavskih jezer, je izjema, saj ima močno podzemno napajanje in iztok (je pretočno) ter se pojavlja med močno zakraselimi in prepustnimi karbonati. $\mathrm{Na}$ podlagi predhodnih raziskav, izdelave nove geološke karte okolice jezera in sedimentoloških raziskav spodnjejurskih plasti predlagamo strukturno-geološki in hidrogeološki model, da bi razložili nastanek in lokacijo jezera. Naše ugotovitve kažejo, da je A) Jezero v Ledvicah del žlebu podobnega vodonosnika $\mathrm{z}$ visečo podzemno vodo, ki se pojavlja $\mathrm{v}$ jurskih plasteh pod dnom doline Triglavskih jezer, B) da so hidrogeološke bariere vodonosnika strukturne (prelomi in nariv) in stratigrafske (plasti gline v spodnjejurskem apnencu), C) da je jezero nastalo v strukturni, hidrogeološki in morfološki depresiji znotraj vodonosnika, D) da se podzemna voda ne napaja izključno iz padavin, ki padejo neposredno na površino vodonosnika, am-
\end{abstract}

\footnotetext{
${ }^{1}$ Department of Geology, Faculty of Natural Sciences and Engineering, University of Ljubljana, Aškerčeva 12, SI-1000 Ljubljana, Slovenia, e-mails: bostjan.rozic@ntf.uni-lj.si, tomi.popit@ntf.uni-lj.si, luka.gale@ntf.uni-lj.si, timotej.verbovsek@ntf.uni-lj.si, ines.vidmar@ntf.uni-lj.si, matej.dolenec@ntf.uni-lj.si,petra.zvabrozic@ntf.uni-lj.si

${ }^{2}$ Geological Survey of Slovenia, Dimičeva ul. 14, SI-1000 Ljubljana, Slovenia
} 
but additionally by subterraneous inflow from the overlying Slatna Nappe aquifer; and E) groundwater outflows from the aquifer at the southern end of the Triglav Lakes Valley, where the Lower Jurassic limestone pinches out.

Key words: high-alpine lake, karstic aquifer, Julian Alps, Triglav Lakes Valley, Jurassic limestone, Southern Alps. pak dodatno s podzemnim napajanjem iz višje ležečega vodonosnika Slatenske tektonske krpe in E) da podzemna voda izteka iz vodonosnika na južnem delu doline Triglavskih jezer, kjer se plastnati spodnjejurski apnenci (in s tem vodonosnik) izklinjajo.

Ključne besede: visokogorsko jezero, kraški vodonosnik, Julijske Alpe, dolina Triglavskih jezer, jurski apnenec, Južne Alpe.

\section{INTRODUCTION}

The bright colours of the Julian Alps are related to the range's carbonate rock composition, in which Late Triassic limestones dominate (Buser 1987, 2009; Jurkovšek 1986; Šmuc \& Rožič 2010). The geological conditions there resulted in the development of a high-alpine karst characterized by extremely deep abysses, caves and surfaces without surface water flows (Kunaver 2004; Hrvatin et al. 2015; Zini et al. 2015). At higher altitudes, springs are very rare and commonly connected to fault zones. The water from rainfall and snowmelt is drained vertically into relatively deep bodies of water that feed large karstic springs, such as the Soča, Boka, Tolminka, Savica and others (Trišič et al. 1997; Janež 2002; Brenčič 2004; Petrič 2004; Brenčič \& Vreča 2016). In such settings, prominent high-altitude lakes are not common, but several smallscale surface water accumulations exist. Their rather small size notwithstanding, they are interesting owing to their mere existence and contribute to the overall beauty of the Julian Alps. In the central Julian Alps, the most celebrated are Krn Lake and the seven lakes of the Triglav Lakes Valley (TLV) (Brancelj 2004, 2015). The origin of these lakes is generally attributed to the impermeable floor composed of glacial sediments, such as tilles (Hrvatin et al. 2015), or to the filling of pores and fractures in the basement rocks with fine glacial material (Brancelj 2004). This is a fine generalization, as lakes all exist in valleys that show a clear glacial morphological overprint. There are seven lakes in the TLV, and the middle one, which is the subject of this paper, stands out for its extraordinary size among them. Owing to its shape or the shape of the boulders along its banks it is known as a Ledvička (which means little kidney) Lake or, as is commonly referred to in literature, Jezero v Ledvicah lake (which translates into "Lake inside Kidneys"). A quick overview of the Jezero v Ledvicah lake's (JLL) banks, however, discourages a glacial-related interpretation of its origin. The eastern banks of the lake are indeed covered by tillite and post-glacial scree deposits, which could cover the underlying tillite. In contrast, the lake water on both the western as well as southern banks comes into direct contact with karstified limestone, mostly the marly and nodular limestone of the Ammonitico Rosso type. Researchers in the past have noted this fact, and it was proposed that these Jurassic beds constitute important water barrier (Gams 1962). Later, they were studied sedimentologically and described as the Prehodavci Formation (Šmuc 2005; Šmuc \& Rožič 2010). Investigations showed that these nodular limestones are actually very pure, and therefore cannot be considered water barriers. A second piece of crucial information that illustrates the extraordinary nature of the JLL comes from a hydrogeological tracing experiment, which showed that the JLL has prominent inflow as well as outflow of groundwater (Urbanc \& Brancelj 1999; Brancelj \& Urbanc 2000). These facts encouraged further research, and a detailed mapping, sedimentological logging and mineralogical analysis were all performed, which culminated in the new solution to the origin question of the JLL presented in this paper.

\section{GEOLOGICAL SETTING}

The studied area belongs to the eastern part of the Southern Alps (Fig. 1), more precisely to the Julian Nappe and Slatna Nappe (Slatna plate in Placer 2008, or Slatna tectonic outlier in Placer 2016), with the latter representing the highest (or second highest) structural unit of this part of the Southern Alps (Placer 1999, 2008; Goričan et al. 2018). The Julian Nappe is dominated by shallow-water carbonates of the Julian Carbonate Platform (Buser 1987; Jurkovšek 1986; Ogorelec \& Buser 1996). This very thick succession is locally interrupted by rather thin, laterally discontinuous ladinian vulcanites and hemipelagic limestones with chert, and latest Carnian/earliest Norian deep-water Martuljek Limestone (Celarc \& Kolar-Jurkovšek 2008; Celarc et al. 2013). The Julian Carbonate Platform is overlain by 
a very thin layer of Middle Jurassic to earliest Cretaceous condensed succession of limestone several meters thick belonging to the Julian High pelagic plateau (Šmuc 2005, Šmuc \& Rožič 2010). The Slatna Nappe consists solely of Carnian massive dolomite and limestone (Jurkovšek 1986; Buser 1987). Thrust structures are further displaced by neotectonic strike slip faults (Placer 1999; Kastelic et al. 2008; Šmuc \& Rožič 2009; Goričan et al. 2018).

In the TLV, the eastern cliffs belong to the Slatna Nappe, whereas the valley floor and western cliffs con- sist of Julian Nappe carbonates. The thrust plane runs below the eastern cliffs and is completely covered by toe-of-slope scree deposits (Šmuc 2005, 2015). The area is characterized by the southward divergent strike-slip Zelnarice and the Špičje fault zones (Fig. 2). The area between the fault zones is characterized by an extensional setting, which is manifested in the NW-SE oriented connecting normal faults, along which southern blocks were lowered. Such a setting played a crucial role in the geomorphological shaping of the TLV (Šmuc \& Rožič 2009).

\section{METHODS}

A detailed geological mapping of the JLL area was performed. Clay interlayers were sampled from outcrops logged in a detailed sedimentological section (1:50 scale) north of the JLL. Clays were analysed for mineralogical composition with a Panalytical PW 3830/40 XRD device, which uses a PW 1820 goniometer and a PW3830 X-ray generator, with a copper tube PW 2273/20 subject to an electric current of $30 \mathrm{~mA}$ and a voltage of $40 \mathrm{kV}$. Clay fractions (less than 2 microns) were separated from the bulk sample by centrifugation and mounted as an oriented aggregate mount for clay-mineral identification. The following treatments were used for the extent of $d$ spacing expansion and contraction indicative of certain clay minerals: air drying, glycol and glycerol hot baths, and heating to $550^{\circ} \mathrm{C}$. Difractograms were analysed with use of X'pert HighScore Plus software, together with the

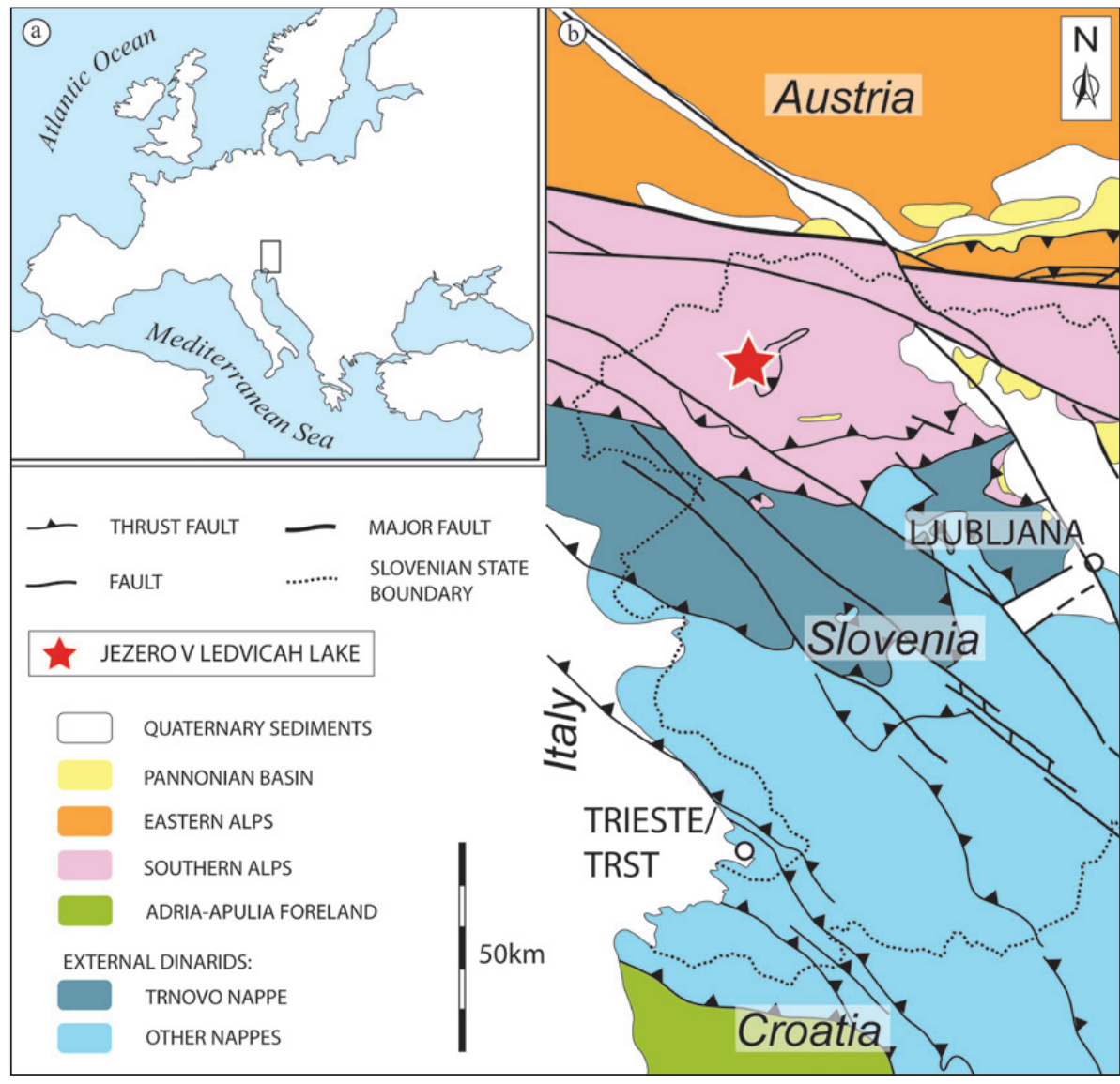

Fig. 1: Location of the Jezero $v$ Ledvicah lake: a) position within Europe; boxed area is enlarged in Fig. $1 b$; b) structural division of western Slovenia (after Placer 2016) with position of the studied area (marked by a star) between the Slatna and Julian nappes. 


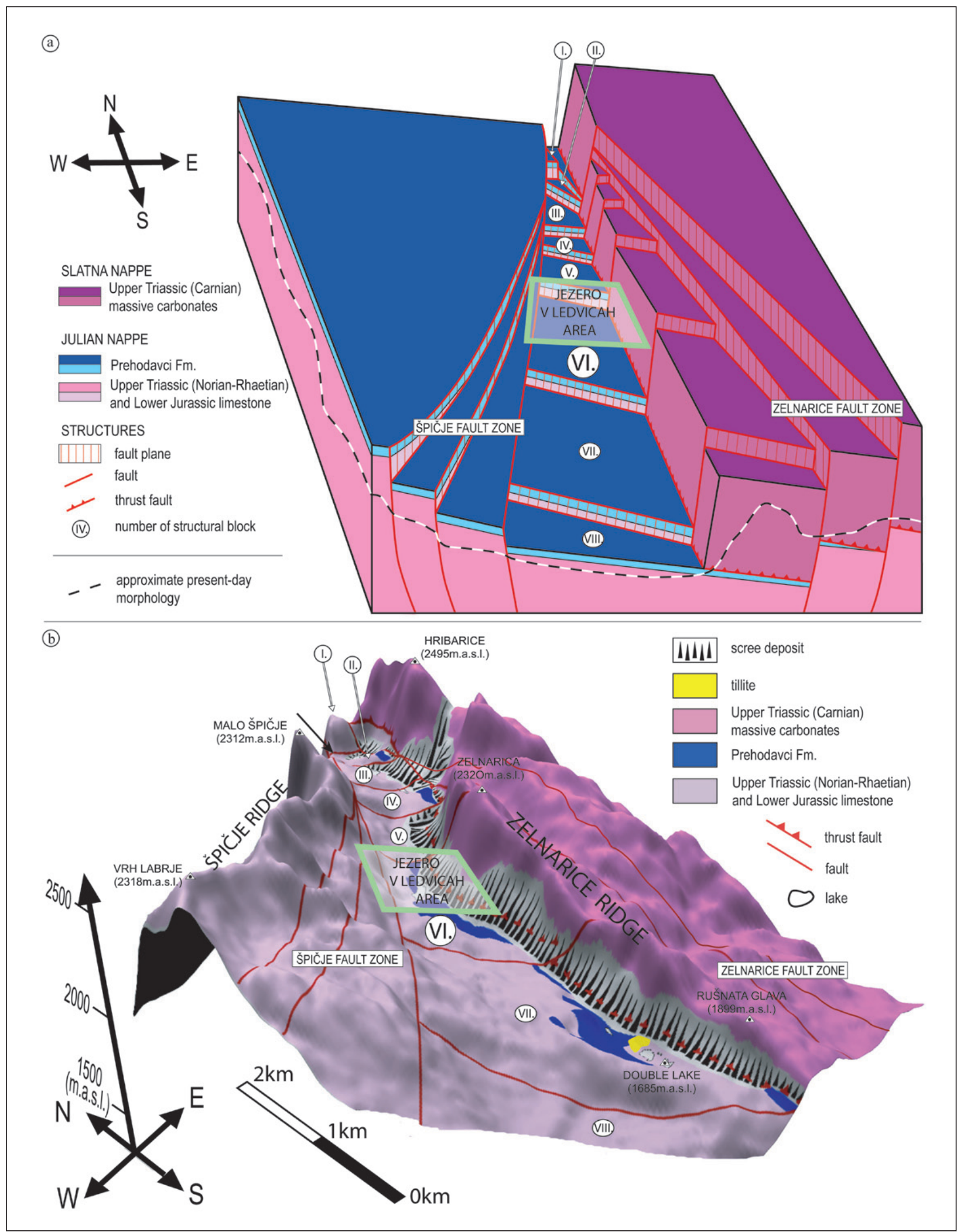

Fig. 2: Structural-geomorphological model of the Triglav Lakes Valley with the Jezero $v$ Ledvicah lake area marked (modified from Šmuc \& Rožič 2009): a) Triglav Lakes Valley formed in the transtensional wedge; b) simplified geological map of the Triglav Lakes Valley placed over the digital elevation model; note that Lower Jurassic and Upper Triassic (Norian-Rhaetian) limestones are not divided in this figure. 
PAN - ICSD database for mineral determinations. Carbonates were also sampled for microfacies and biostratigraphic research. The extent of the aquifer was assessed by combining the data from previous mappings (Šmuc \& Rožič 2009), a detailed geological map of the JLL area, and a surface analysis of a shaded digital elevation model with a spatial resolution of $1 \mathrm{~m}$ taken from a lidar scanning in 2014-2015. On the latter, the transition from Lower Jurassic oolithic megabed to bedded limestone (approximate aquifer boundary) is well recognizable and served to delineate the aquifer's western margin.

\section{DESCRIPTION OF THE MESOZOIC SUCCESSION AND QUATERNARY UNITS}

The oldest rocks in the mapped area are Carnian massive carbonates (dolomite and limestone) that form the eastern cliffs of the TLV and belong to the Slatna Nappe (Figs. $3 \& 4$ ) and therefore have no direct influence on the JLL. Their indirect role is manifested only as they act as the source-rock for the scree apron that covers the thrust-face and terminates at the eastern banks of the JLL (Fig. 5a).

In the Julian Nappe, a tectonic unit that directly underlies the JLL, the succession begins with very thick Dachstein Limestone, the main constituent of some impressive cliffs in the Julian Alps. It is well bedded and exhibits lofer cycles (Ogorelec \& Buser 1996). In the mapped area it comprises the western flanks of the valley and is followed by a megabed composed mainly of ooidal limestone (Fig. 5b) several tens of meters thick. The onset of intense ooidal production marks the beginning of the Jurassic beds (Buser 1987, 1989; Jurkovšek 1987).

It is overlain by a Lower Jurassic succession of alternating, well-bedded micritic and fine-grained pelletal limestone (Fig. 5b) 90 meters thick, exhibiting common signs of subaerial exposure such as fenestrae and emersion surfaces marked by breccias filled with greenish marl. Thin sections made from limestones show microbial growth structures (occasionally in the form of oncoids). Other rare facies are medium-grained peloidal and bioclastic (bivalves, gastropods) limestone. Among fossils, Thaumatoporella sp. is common, and foraminifers Siphovalvulina sp., Earlandia sp., Textulariidae, Valvulinidae and nodosarid Lagenina were detected. This speciespoor assemblage is characteristic for lowermost Jurassic shallow marine carbonates all over the peri-Mediterranean area (e.g., Chiocchini et al. 1994; Boudagher-Fadel et al. 2001; Barattolo \& Romano 2005; Mancinelli et al. 2005; Pomoni-Papaioannou \& Kostopoulou et al. 2008; Tunaboylu et al. 2014), and also for the Lower Jurassic beds of the Julian Carbonate Platform (Jurkovšek 1987). These beds strike from the NE towards the SW corners of the mapped area and run through the central part of the investigated area along the JLL, where they even form small portions of the JLL banks. During the mapping, four thin beds (up to $15 \mathrm{~cm}$ thick) of green clays were discovered, logged in the detailed sedimentological section, and sampled in the outcrops at the NE margin of the investigated area (Fig. 5b - enlarged box). They occur within basal $16 \mathrm{~m}$ of this unit. The first bed occurs approximately $3 \mathrm{~m}$ above an oolithic megabed (the first two meters are covered by a scree deposit). It is $4 \mathrm{~cm}$ thick and composed almost exclusively of illite, subordinate K-feldspar and chlorite and traces of pyrite (Tab. 1). Upwards, after a carbonate interbed $2 \mathrm{~cm}$ thick a second bed follows, which is $3 \mathrm{~cm}$ thick and composed of carbonates (calcite and dolomite) but also contains illite (assessed to $22 \%$ ) and traces of K-feldspar. A third bed occurs approximately 9 meters above the oolithic megabed, and is $15 \mathrm{~cm}$ thick and light green in the lower $7 \mathrm{~cm}$ and dark green in the upper $8 \mathrm{~cm}$. The lower part displays a composition similar to the second bed, but contains less illite (15\%) and no K-feldspar. In contrast, the upper part is composed almost exclusively of illite (assessed to 96\%), with some chlorite and traces of dolomite and pyrite. Clays actually show a mixed layer of smectite/illite. The fourth bed occurs approximately 16 meters above the oolithic megabed and is $15 \mathrm{~cm}$ thick. In the lower part some thin limestone nodular beds are interlayered, whereas the upper part is composed solely of a clayish material composed predominantly of illite (67\%), 30\% calcite and traces of chlorite, kaolinite and pyrite.

These beds correlate with the clay interlayer reported from the northern cliff of the Mt Kanjavec ridge (Herlec et al. 2009), which closes the TLV at its northern end. Authors report a green-clay (pyroclastic) interbed located above the oolithic megabed. They analysed clays in three locations inside the TLV, one possibly the same as that in our studied section. Although they do not provide details on mineralogy, these clay layers display mixed-layer characteristics and therefore correspond to the clay mineralogy detected in our section. We propose that the clay interlayers are most likely continuous and spread at least across the area of the TLV. Here we notice that Herlec and co-authors (2009) report also other, more distal findings of similar interlayers, which occa- 


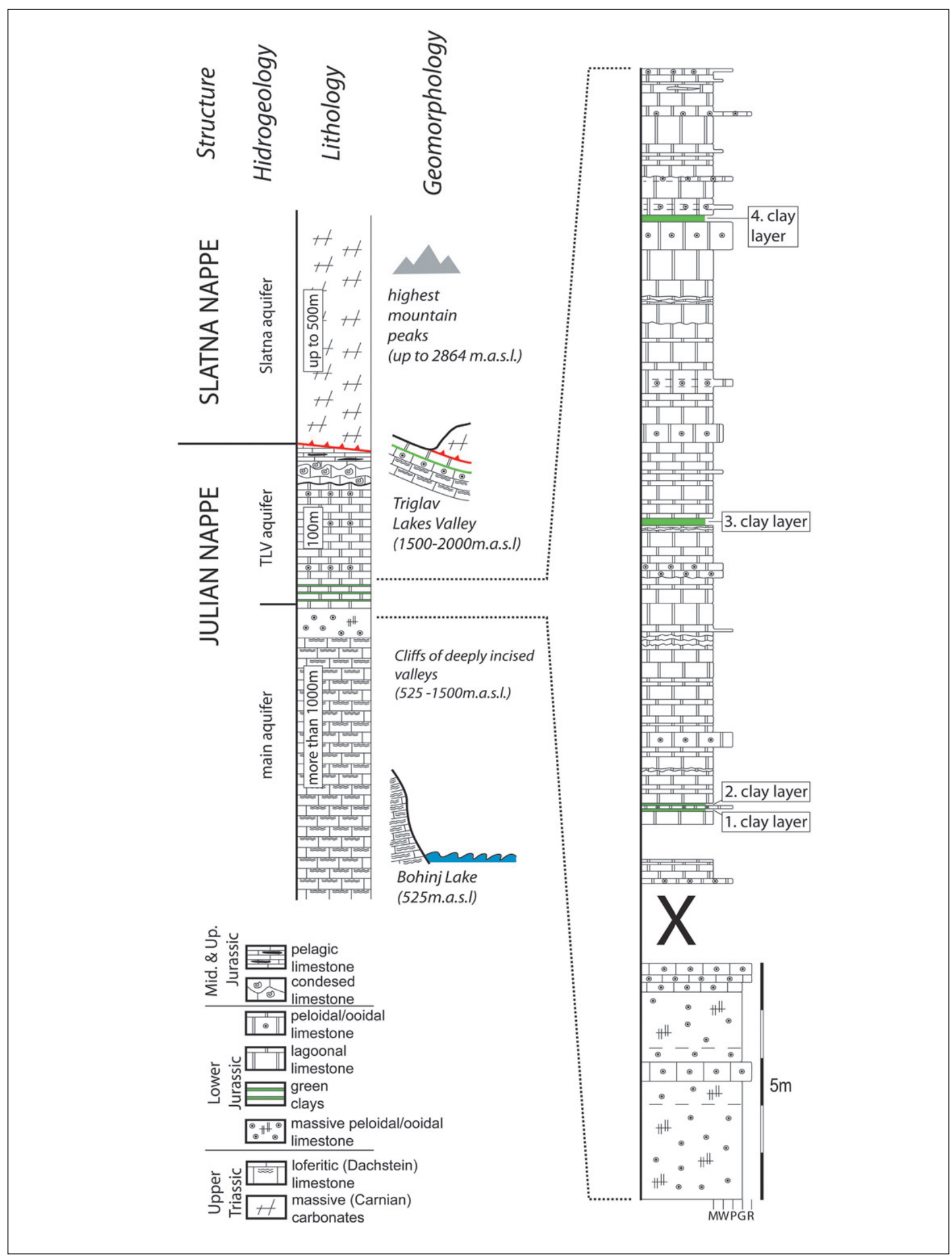

Fig. 3: Schematic succession of the Triglav Lakes Valley area with detailed section containing clay interlayers. 
Tab. 1: Mineralogical analysis of clay-rich beds (in \%).

\begin{tabular}{|c|c|c|c|c|c|c|c|c|c|}
\hline Bed & Sample & Illite & K-Feldspar & Chlorite & Dolomite & Calcite & Kaolinite & Pyrite & Mixed layer \\
\hline 1 & LED-8.25 & 93.9 & 1.6 & 3.1 & - & 1.3 & - & 0.1 & - \\
\hline 2 & LED-8.40 & 22.2 & 0.3 & TRACE & 46.5 & 31.0 & - & - & - \\
\hline \multirow{2}{*}{3} & LED-14.35 & 15.1 & - & - & 35.0 & 49.9 & - & - & - \\
\cline { 2 - 11 } & LED-14.45 & 95.8 & - & 3.8 & 0.1 & - & - & 0.3 & Sm/III \\
\hline \multirow{2}{*}{4} & LED-20.9 & 67.5 & - & 0.8 & - & 30.6 & 0.8 & 1.1 & - \\
\hline
\end{tabular}

sionally have montmorillonite clays, indicating their volcanogenic origin.

The youngest rock-unit belongs to the Prehodavci Formation (Šmuc 2005). It is several meters thick and composed of nodular, grey and red limestone of the Ammonitico Rosso type (Figs. 5c-e). At the base of the formation, ferromanganese nodules indicate stratigraphic gaps within this condensed Middle and Upper Jurassic formation. The formation formed after platform drowning, which turned into a submarine plateau known as the Julian High (Šmuc 2005). In the Julian Alps this formation is overlain by end-Jurassic Biancone Limestone, which is thin-bedded, light-coloured pelagic limestone with chert nodules. These beds outcrop sporadically in the TLV (Šmuc 2005, 2015), but were not detected in the mapped area. They are either cut off by the Slatna thrustfault or covered by scree deposits.

Among Quaternary deposits a tillite sedimentary body was mapped on the southern banks of the JLL. It is surrounded by Holocene scree and rock-fall deposits. Scree covers eastern flanks of the entire TLV and originates from the steep upper portions of the Zelnarice Ridge. We divided scree deposits into three "generations" due to the intensity of plant coverage there. Rock-fall deposits originate from both sides of the valley, occur at several locations, and two "generations" were outlined using the same criteria as for the scree. On the SW banks of the JLL the banks are flat and covered with marsh vegetation.

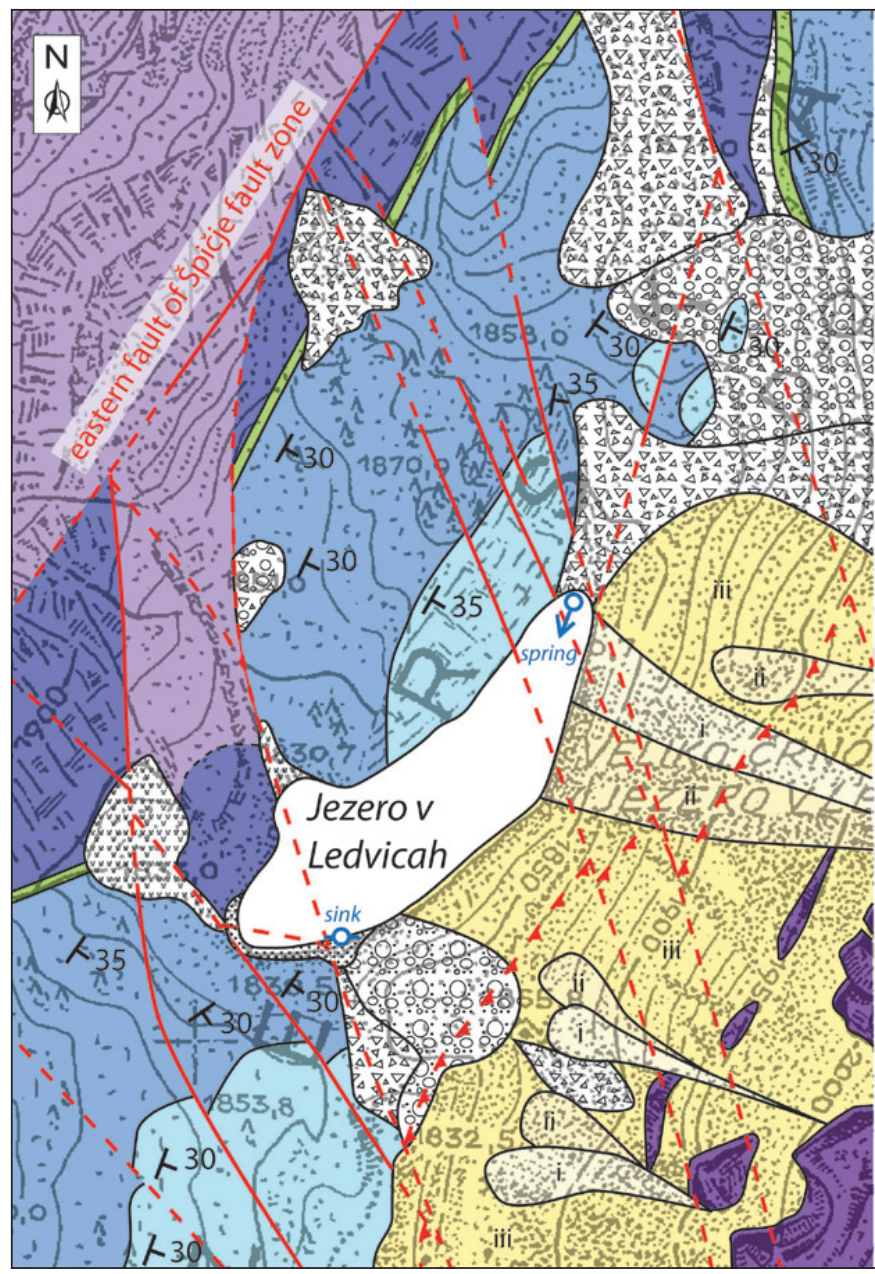

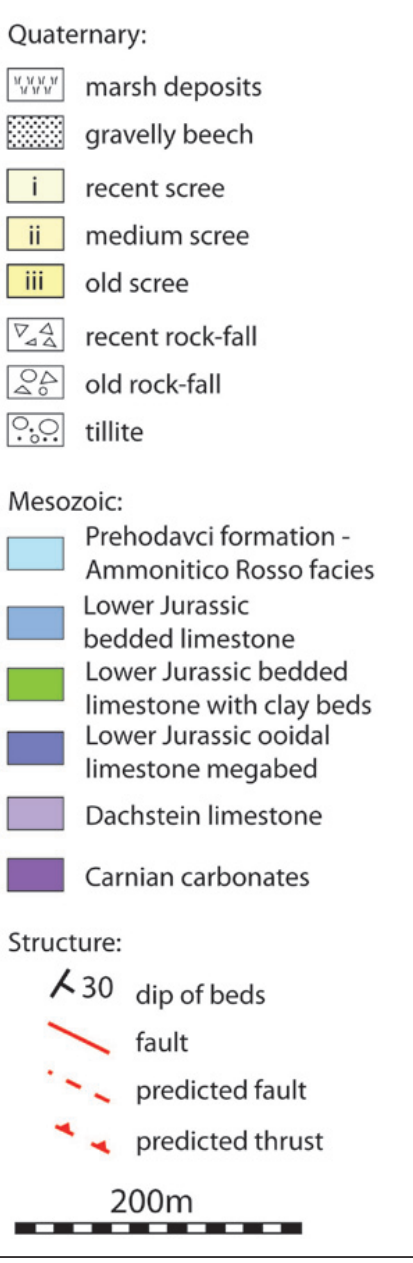

Fig. 4: Detailed geological map of the Jezero $v$ Ledvicah lake area. 


\section{STRUCTURE OF THE JEZERO V LEDVICAH LAKE AREA}

The thrust-fault of the Slatna Nappe was recognized regionally, but is completely covered in the mapped area by a scree-apron that runs along the Zelnarice Ridge. Several neotectonic strike-slip faults were mapped in the JLL area. These faults belong to a large-scale divergent strike-slip fault zones that produced extensional area in the fault-wedge. This structural setting was proposed as having played a crucial role in the origin of the TLV as well as its present geomorphology (Šmuc \& Rožič 2009).

In the mapped area the easternmost fault of the Špičje fault zone (Fig. 2) was recognized in the NW part (from here below written solely as Špičje fault) and represents the most prominent structure. It separates the Dachstein Limestone on the NW from the (almost exclusively) Jurassic limestones on the SE. From the Špičje

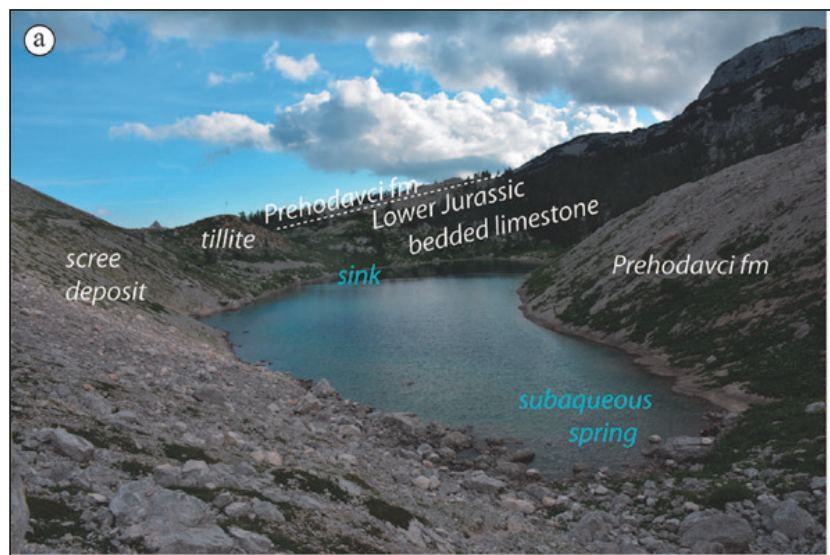

(c)

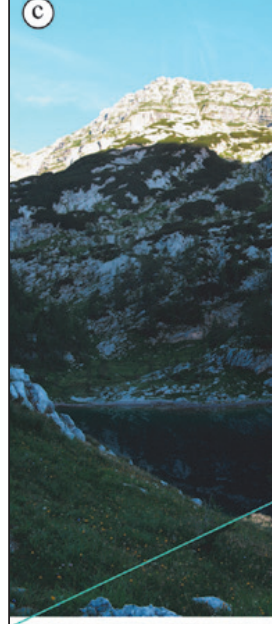

(d)

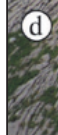

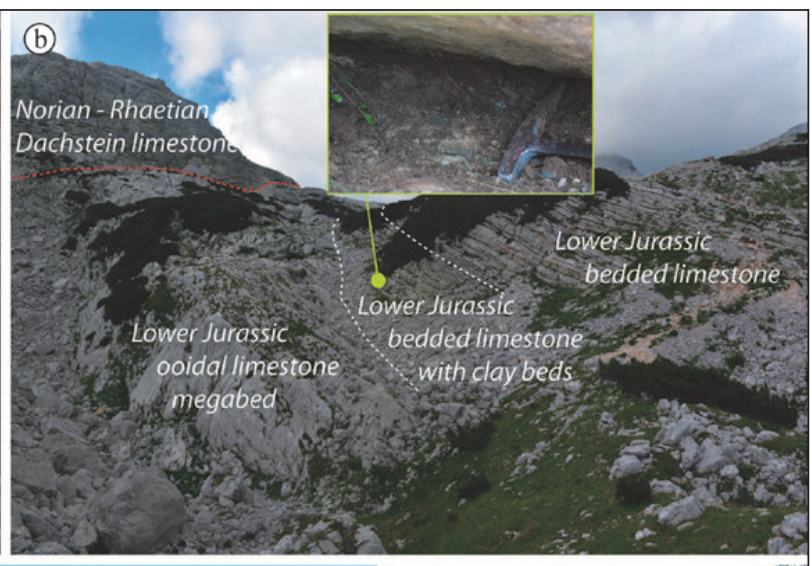

(e)

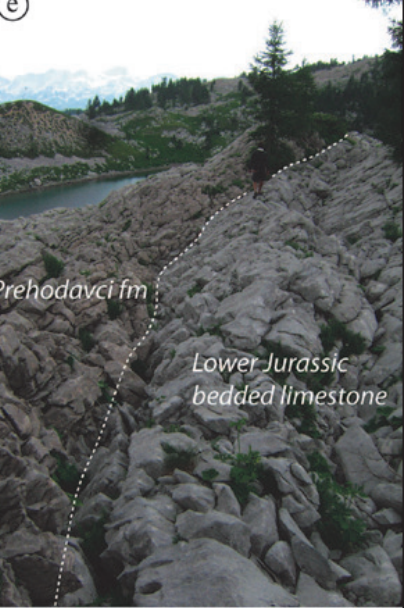

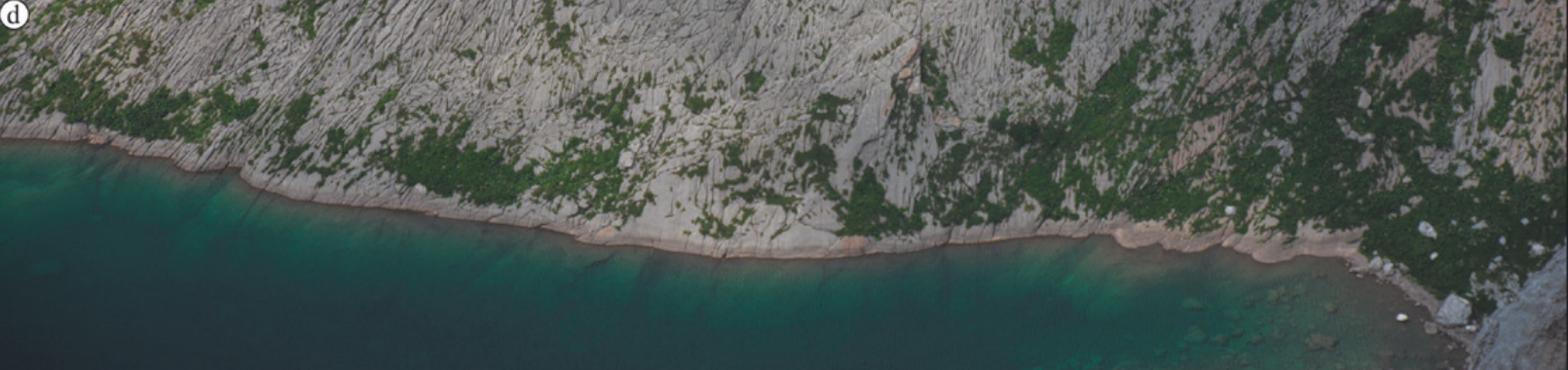

Fig. 5: Geology of the Jezero v Ledvicah lake area: a) eastern banks (left) are covered by scree and glacial deposits, western banks (right) are in direct contact with rock basement, b) clay interlayers occur within basal 16 meters of the Lower Jurassic bedded limestone (see boxed area for close-up view), c-d) limestone of the Ammonitico rosso facies forms the western cliff, bank and floor of the lake, e) karstified contact between Lower Jurassic bedded limestone and Prehodavci Formation at the top of the western cliff. 

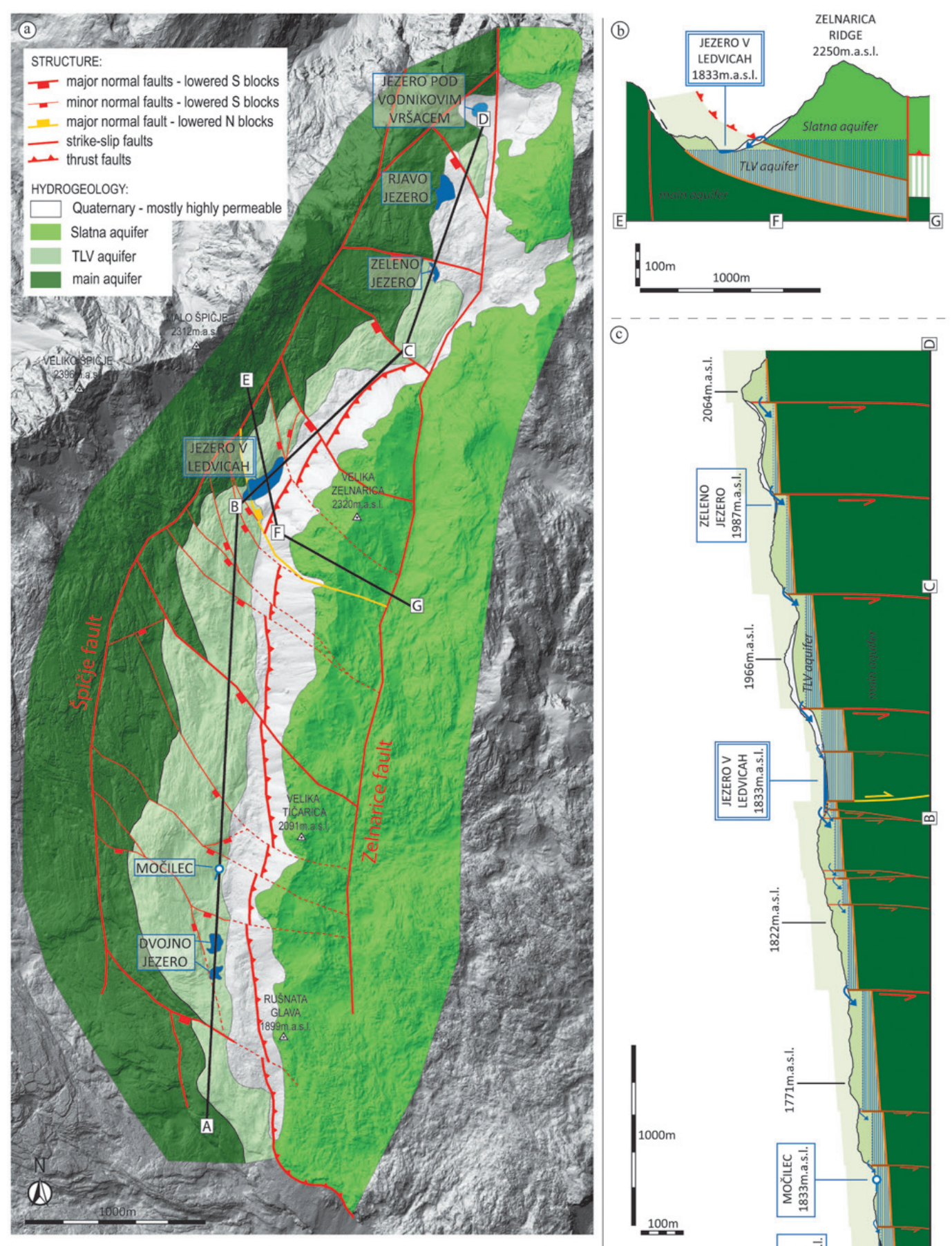

()

LITHOSTRATIGRAPHY AND STRUCTURE OF FIGURE 4:

HYDROGEOLOGY OF CROSS-SECTIONS

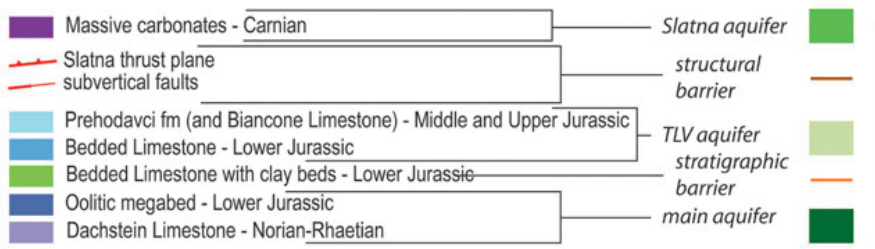

a spring

subterraneous

groundwater overflow

predicted

groundwater level

groundwater

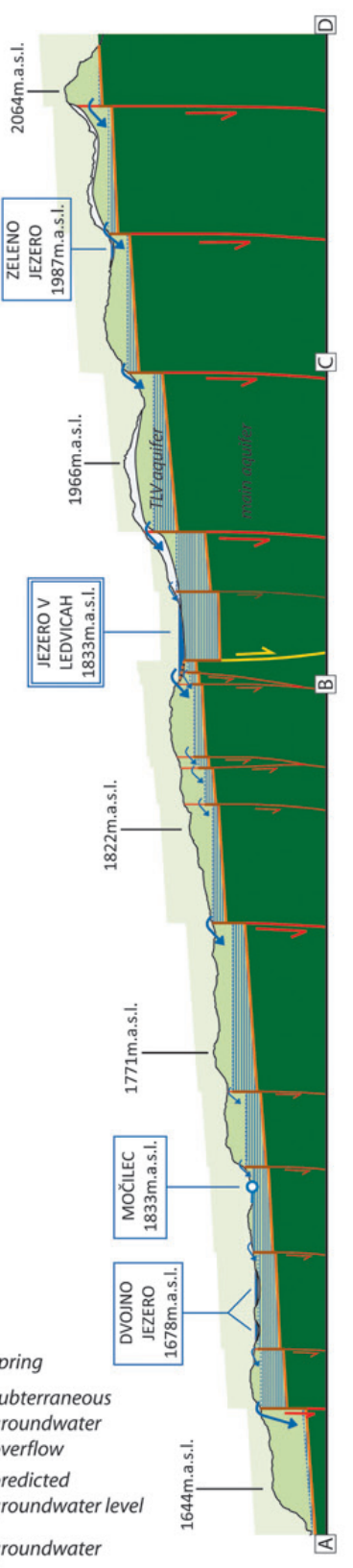

Fig. 6: Hydrogeology of the Triglav Lakes Valley: hydrogeological map and schematic cross-sections of the Triglav Lakes Valley aquifer. 
fault several faults branch out, displace Jurassic units and disappear in the scree deposits. These faults are connecting faults between the Špičje fault and the western fault of the Zelnarice fault zone (from here below written solely as Zelnarice fault). Among these connecting faults, two show prominent displacements, whereas movements among the others are minor. Consequently, the entire rock mass of the valley floor in the mapped area can be divided into three relatively coherent blocks. The first prominent fault is at the NE margin of the mapped area and lowers the SW-located tectonic blocks. In contrast, the fault that runs through southern part of the JLL shows a down-faulting of the NE block. This promotes a lowering of the central block, above which the JLL is situated. All beds of the Julian Nappe dip at angles of 30 to 35 degrees towards the ESE.

\section{ORIGIN OF THE JEZERO V LEDVICAH LAKE}

The geological structure played a crucial role in the formation of the entire TLV. It originated with a tectonic subsidence within a divergent strike-slip fault wedge. Transtensional conditions are manifested by the continuous down-throwing of blocks along the connecting faults, which can be traced throughout the entire valley. Such structure is reflected in the "stair-like" topography of the TLV floor that is still recognizable, despite the reshaping of the glacier (Fig. 2; for details see Šmuc \& Rožič 2009). In the JLL area, however, this general structural trend is interrupted (Fig. 6). Namely, the central tectonic block (the basement block of the JLL) is lowered against the NE block, which is in accordance with the general trend here. But simultaneously, it is lowered also against the SW block, in opposition to the general setting. Such conditions are reflected also in specific geomorphological conditions, where the generally "stair-like" descending valley floor is interrupted by an opposite step. It could produce specific, local conditions also during glaciations, and during retreat of the glaciers the depression could be more pronouncedly filled by till. This is probably indicated in the tillite accumulation that occurs on the SE margin of the JLL (tillites are otherwise rare in this part of the TLV). However, even if the depression existed during glaciation, the lake's solely glacial origin is unlikely, as the tillites form only part of the JLL banks (and floor).

On the western and southern banks the lake water comes in direct contact with Jurassic limestone, where both Middle to Upper Jurassic condensed limestone as well as Lower Jurassic bedded limestone are present (Figs. 5c, e). It is particularly evident in the western bank, where rock-faces can be seen several meters below the water surface (Fig. 5d). Both lithostratigraphic units show very intense karstification in the entire mapped area, and in the area directly behind the banks a wellexpressed grikes mimic the tectonic setting of the valley (Figs. 7a, b). Some small-scale vertical cave-shafts were also detected (Fig. 7c). Other specific karstic features are rillenkarren on the shore-face (Fig. $7 \mathrm{~d}$ ), which dendriti- cally branch out and gain in density towards the JLL surface and are related to intense rock-dissolution in specific microclimatic conditions where near-surface moisture (condensed water) plays an important role (Herlec 2009). It is unlikely that such intensively karstified (porous) rocks would form a lake water barrier, and a more complex model (compared to existing models) is needed.

We propose a hydrogeological model of a smallscale aquifer with perched groundwater that exists below the JLL floor. The main barriers of this aquifer are of two kinds. The first are the prominent faults, which result in strong rock deformations and serve to deflect groundwater in karst systems (named as deflector faults in: Šušteršič et al. 2001; Šušteršič 2006; Čar 2018). The faults in the TLV are mostly vertical and therefore represent the lateral barriers of the aquifer. A particularly strong barrier is expected in the easterly-located Zelnarice fault (Fig. $6 \mathrm{~b}$ ), which represents a major fault in the fault wedge described above. The second kind of barrier is stratigraphic, and is represented by several clay interlayers that occur within the Lower Jurassic bedded limestones just above the thick oolithic megabed. It represents a generally vertical barrier but is, however, slightly inclined towards the $\mathrm{E} / \mathrm{SE}$ as it follows the dipping of the beds. In our model, clay interlayers separate the small-scale upper aquifer from the underlying large-scale aquifer composed of a thick succession of Late Triassic limestones including the oolithic megabed. This large aquifer has predominantly unconfined characteristics, a thick vadose zone, and gathers rain and snowmelt waters towards the strong, low-altitude Savica spring (and others) that finally fill the large glacial Bohinj Lake in the Bohinj Valley (Trišič et al. 1997; Brenčič \& Vreča 2016). Like the large-scale aquifer below, the small upper aquifer of the JLL area is also karstic and feeds from local rainfall and snowmelt. The large- and small-scale hydrogeological systems are therefore generally similar, but the scale, characteristics and surface-interaction of the groundwater differ.

We propose that a large part of the TLV shallow 
subsurface actually forms small-scale interconnected aquifers, with the aquifer the JLL area (described above) being just one of them (Figs. $6 c \& 8$ ). It is more correct to describe it as a single segmented aquifer, which we call the Triglav Lakes Valley aquifer (TLV aquifer). In the TLV aquifer each particular segment is defined by boundaries of corresponding tectonic block. Due to the described structural setting, tectonic blocks (aquifer segments) are gradually lowered towards the south, together with the valley floor. The system works as a "gutter" that distributes groundwater along the axis of the valley. The main barrier of the "gutter" consists in the vertical Zelnarice fault to the east and the generally eastward-dipping clay interlayers in the remaining part of the aquifer. In this system, each lower (southern) segment is fed by groundwater from the upper (northern) segment.

An atypically lowered block at the JLL is an exception in the general setting and acts as a depression within the gutter. In this hydrogeological and morphological depression the groundwater accumulates and probably even "outcrops" in the form of the JLL. With such a model we can explain the subaqueous water inflow in the northern part of the lake and the outflow in the southern part of the lake (Urbanc \& Brancelj 1999), where water re-enters the "classically shaped" gutter system. We can say that the JLL water represents the exposed part of the entire system, where the exposition is directly connected to the anomaly of the gutter of the TLV aquifer.

Our hydrogeological model is supported by a tracer test that proved the connection of the groundwater flow between JLL and the Močilec spring (Urbanc \& Brancelj 1999, 2002; Brancelj \& Urbanc 2000). The Močilec spring is located approximately $2 \mathrm{~km}$ south, very close to the Dvojno jezero Lake ("Double Lake") (Fig. 6). The spring is typically karstic, as it displays high variations in water outflow. The water springs just below one of the connecting NW-SE faults, flows along the surface for a small distance, and sinks back into a particular segment of the aquifer. Only during extreme water events (e.g., snow-melt combined with heavy rain) does it reaches the Dvojno jezero Lake, which is otherwise characterized by rather stagnant water (Brancelj \& Urbanc 2000; Muri \& Brancelj 2002) and which is therefore a glacial lake (accumulated in the depression with the floor sealed by glacial material).

Another spring called Izvir pod Rušnato Glavo occurs $1.1 \mathrm{~km}$ further south. It could represent the final outflow from the "gutter" aquifer; or perhaps more ac-
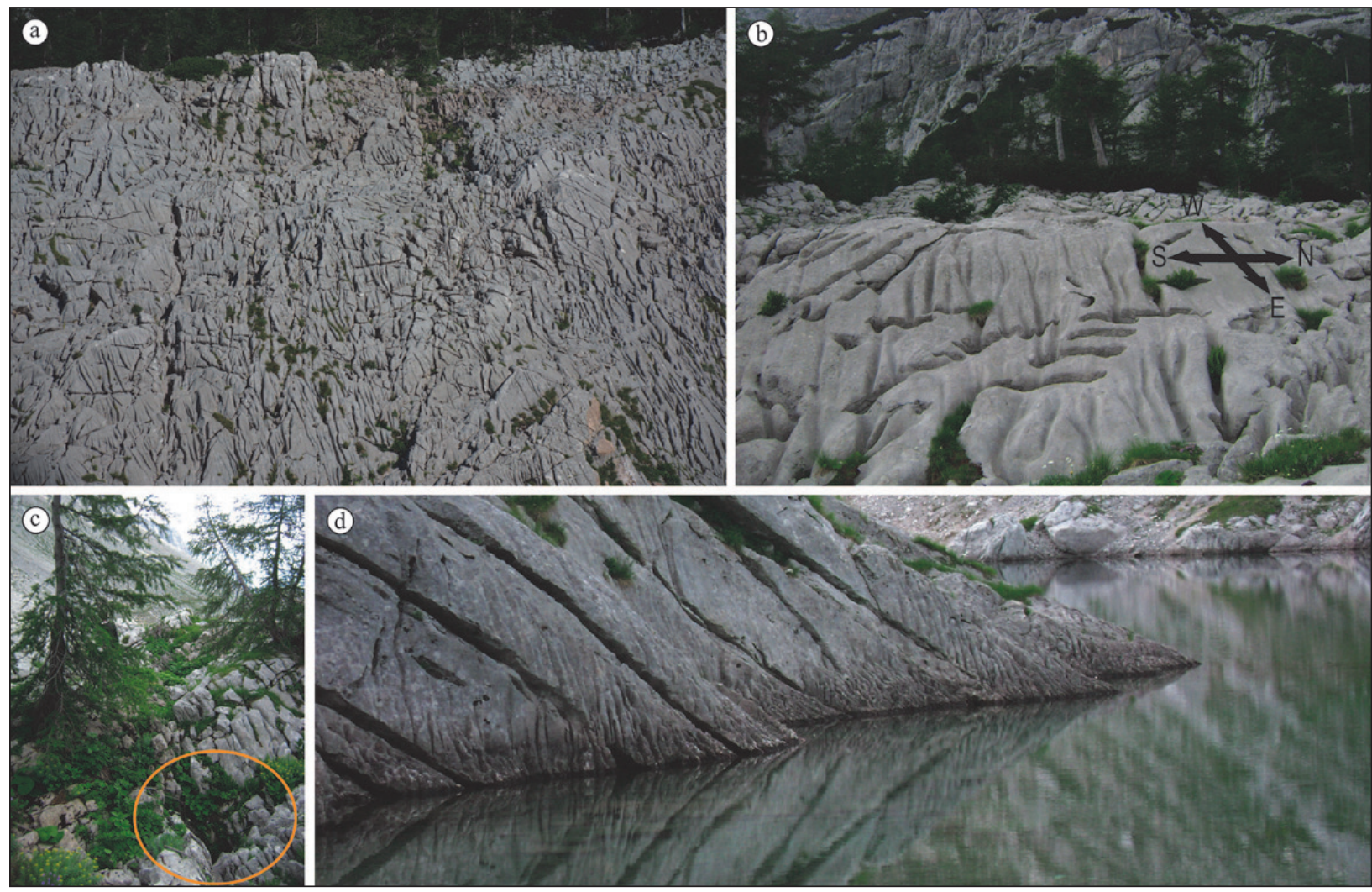

Fig. 7: Karstification of Jurassic limestones from the western cliff of the Jezero $v$ Ledvicah lake: $a$-b) grikes are oriented mainly in the N-S and NW-SE directions and mimic the tectonic structure of the area, c) entrance to the small cave-shaft (circled) just behind the cliff edge, $d$ ) rillenkarren dendritically branch out and gain in density towards the lake surface. 


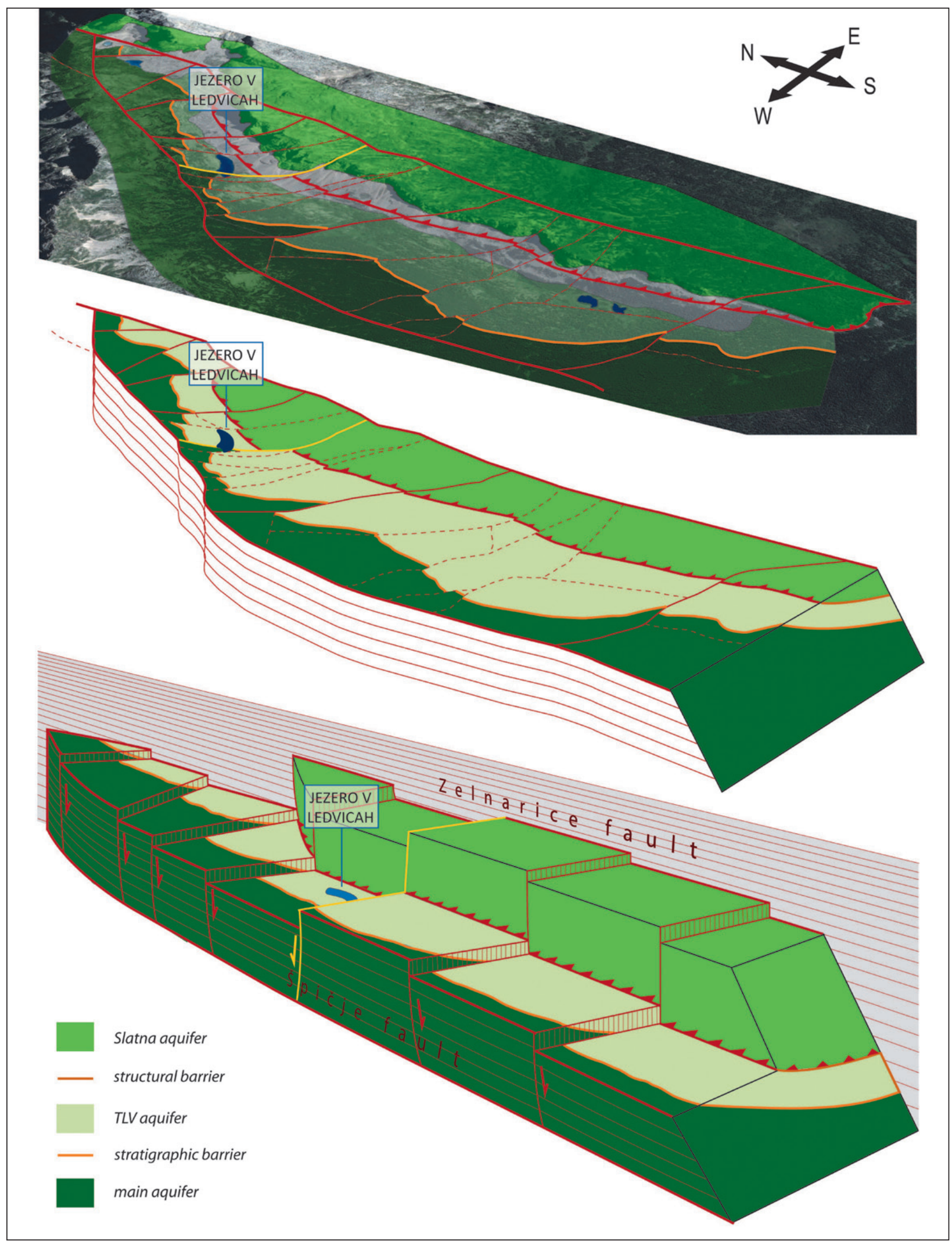

Fig. 8: Hydrogeological model of the Triglav Lakes Valley aquifer with 3D view of hydrogeological map placed atop the satellite image (above; source Google Earth), without satellite image (middle) and schematic hydrogeological model (below). 
curately, one of the outflows, as quantities of the water in this spring are smaller than those detected in the JLL and the Močilec spring. Unfortunately, Urbanc and Brancelj $(1999,2002)$ do not provide information on the connection in the course of their trace experiment.

The same tracer test indicated the co-existing connection of the JLL waters to the Savica spring, i.e., the main outflows from a large-scale aquifer, and is explained by two non-exclusionary interpretations. The first is related to the final outflow of groundwater from the gutter at the end of the valley, where Jurassic rocks wedge out along the prominent fault. Part of the outflow could be directed through the minor Izvir pod Rušnato Glavo spring, but water flows out of the TLV aquifer subterraneously, either through direct connections in karstified rocks or through springs covered by scree deposits. The second option is derived directly from the detailed geological map presented herein. In the southern part, the JLL borders the Lower Jurassic bedded limestone as well as the oolithic megabed at the SW banks. As stated previously, the boundary between these two lithostratigraphic units functions as the approximate barrier between the small-scale aquifer, i.e., the gutter system and a main aquifer. In this part of the lake a prominent fault crosses the lake and glacial till additionally occurs. Such a complex setting can result in very specific conditions, where part of the lake water outflow feeds the springs in the lower part of the valley (continues to flow inside the TLV aquifer), whereas another part of the outflow contributes directly to the waters of the Savica spring. If so, the major outflow from the lake surely re-enters the TLV aquifer, as Urbanc and Brancelj (1999) identified the main sink in the SE part of the lake. The direct outflow from the lake to the oolithic megabed of the main aquifer would be directed through the marshland at the SW end of the lake, and it would be minor and probably be limited exclusively to extreme water events.

When we examine the entire TLV, we see that in the south-eastern part the rocks that form the TLV aquifer are covered by Slatna Nappe carbonates and the thrust plane acts as a barrier, thus inhibiting any direct hydrogeological connection with the TLV aquifer. Because strike-slip faulting postdates the thrusting, the dolomite cover is segmented by the same faults as the underlying rocks of the TLV aquifer. We propose that part of the Slatna Nappe, which is situated between the Zelnarice fault and the Slatna thrust plane (Zelnarice Ridge), forms organized small-scale aquifers organized very similar to the TLV aquifer below. But there is an important difference: the lowest point of each particular segment of the TLV aquifer (where the groundwater outflows from the segment) is located in the central part of a "gutter". Consequently, the groundwater overflows into the next segment of the aquifer and remains inside the "gutter". In contrast, the lowest (potential outflow) points of the Zelnarice Ridge tectonic blocks (aquifers) are distributed along the scree-covered Slatna thrust plane that runs along the TLV. We propose that water infiltrated in this area leaves the Zelnarice Ridge aquifers subterraneously at these points, overflows the thrust plane, and infiltrates through the scree deposit to the underlying TLV aquifer.

In the NE part, the TLV aquifer comes into contact with the Slatna Nappe carbonates along the Zelnarice fault and the contact is therefore lateral (not vertical, as it is further south). This contact is also entirely covered by a scree deposit. Although less certain, a subterraneous water inflow from this part of the Slatna aquifer into the TLV aquifer cannot be excluded.

\section{HYDROGEOLOGICAL CALCULATIONS}

In order to test the validity of the proposed hydrogeological model we used the water balance approach to calculate the recharge area of the TLV aquifer. For the water balance calculations, we used previously estimated discharge data and performed snow-water equivalent (SWE) modelling, since snowmelt is the main contributor to the recharge process in these high-altitude parts during the time period studied (spring/early June).

The input part of the water balance for the TLV aquifer was equated with the difference in daily SWE, modelled by a degree-day point model that uses precipitation and temperature data to model SWE (DeWalle \& Rango 2008). Although less precise than an energy-balance ap- proach, the degree-day approach requires less data but still produces results comparable to other methods (Rango \& Martinec 1995). It has been reported that despite their shortcomings in terms of temporal and spatial variability accuracy, such conceptual models generally outperform energy-balance models on catchment scales (Hock 2003). In order to calculate the water balance input, several empirical parameters needed to be estimated, among them: critical temperature to determine the precipitation event type, degree-day factor and base temperature in order to determine melt rates, surface temperature factor and coldcontent degree-day factor to determine rate of change in cold content, and liquid-water holding capacity to deter- 


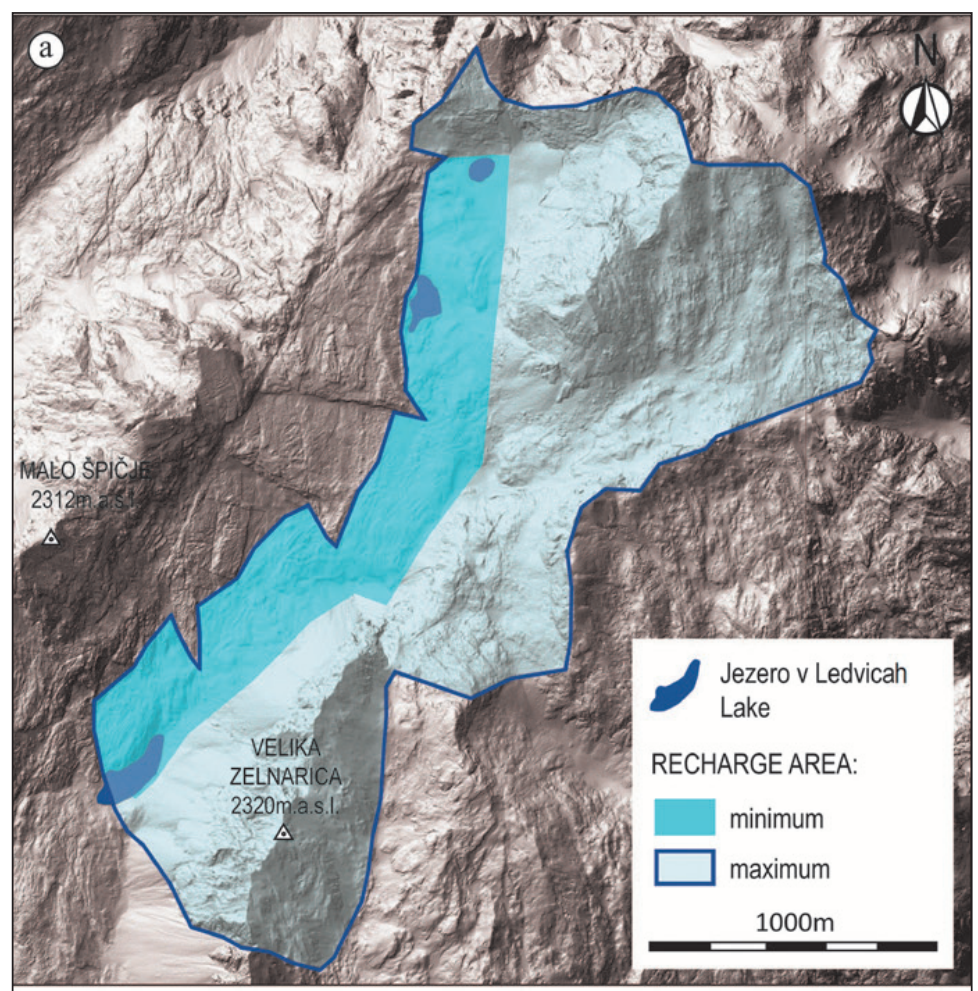

(b)

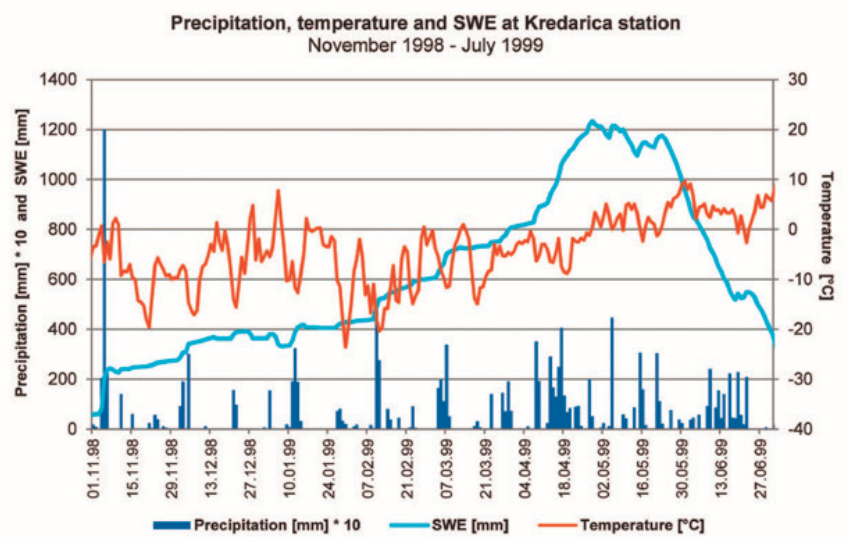

(C) Seasonal SWE at Kredarica station

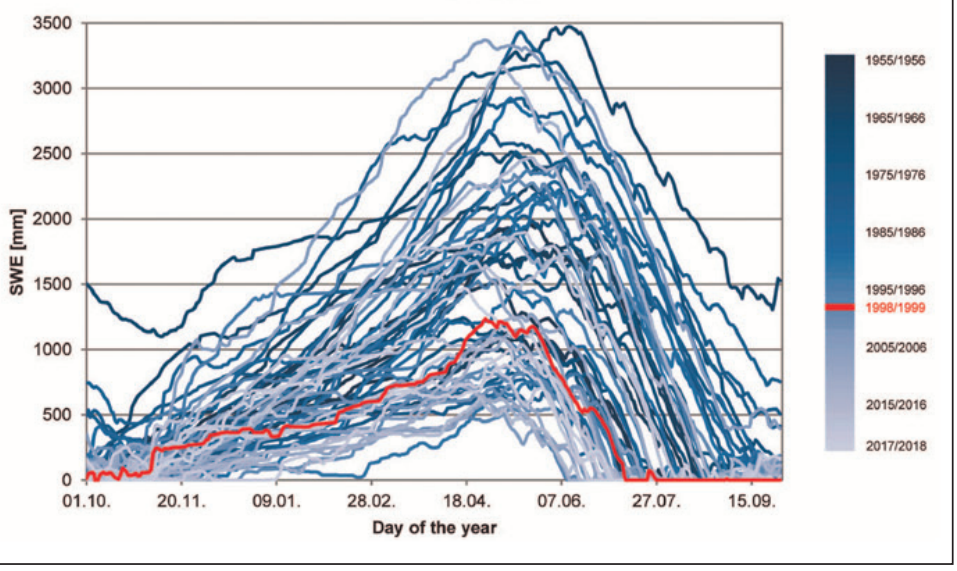

Fig. 9: Hydrogeology of purported recharge area: a) minimum recharge area covers only the guttershaped TLV aquifer; maximal recharge area proposes scree-covered inflow from Slatna aquifer (from areas of vertical as well as lateral contacts), b) precipitation, temperature and SWE at Kredarica station, November 1998-July 1999, c) comparison of seasonal SWE at Kredarica station 1955-2018. 
mine the start of drainage from the snowpack. Daily SWE for the 1998/1999 winter season was determined using meteorological data from the Slovenian Environment Agency for the Kredarica station (ARSO 2018). The station is located approximately $6.5 \mathrm{~km}$ northeast of the JLL. Fig. 9 shows the proposed minimum and maximum recharge areas, the measured precipitation and temperature data, as well as the modelled SWE data for the Kredarica meteorological station from November 1998 to July 1999 (for details see Vidmar 2015; Vidmar \& Brenčič 2018). The period 1998-1999 was used, as the only tracer test was performed in this period.

The water balance of the entire TLV aquifer is not known due to its complex karstic characteristics. Therefore, previously estimated discharge values from part of the aquifer were used. The results of the tracer test in June 1999 represent the only available discharge data for the TLV aquifer at the JLL location (Urbanc \& Brancelj 1999). The discharge values were determined based on the estimated lake volume from older data amounting to $135,000 \mathrm{~m}^{3}$ (Gams 1962) and the measured concentrations of the tracer along the lake during the tracer test that was used to estimate the volume of fresh water that entered the lake during the two days of monitoring. According to the results, the discharge of the lake was 0.729 $\mathrm{m}^{3} / \mathrm{s}$ on 13 June 1999 , and $0.822 \mathrm{~m}^{3} / \mathrm{s}$ on 14 June 1999 . The tracer test confirmed the direct connection between the JLL and the Močilec spring at a distance of approximately $2 \mathrm{~km}$ downstream, where the tracer concentration reached its maximum 6 days after injection into the lake. Assuming similar characteristics along the entire length of the TLV aquifer, we calculated its recharge area upstream of the JLL using the modelled daily SWE difference and the measured daily discharge and aquifer stor- age time from the tracer test by means of the following equation:

$$
A=\frac{Q t}{\Delta S W E}
$$

where:

A $\quad$... recharge area of TLV aquifer upstream of the Jezero v Ledvicah lake

Q $\quad \ldots \quad$ discharge estimated during 1999 tracer test

$t \quad \ldots \quad$ time step (= 1 day)

$\triangle S W E$... daily difference in modelled SWE value

Using the given equation we calculated the recharge area using the estimated discharge on a given day (e.g., 13 June 1999) and the daily SWE difference 6 days prior to the discharge estimation (e.g., 6-7 June 1999). Two discharge estimations led to two recharge area calculations: $3.00 \mathrm{~km}^{2}$ for the first day, and $3.38 \mathrm{~km}^{2}$ for the second day. In order to avoid the bias and uncertainty stemming from the use of specific data in a simple empirical lumped model, a third calculation was made using the average SWE differences in the period two weeks prior to the discharge estimations while also averaging the two discharge values, which resulted in a recharge area of $2.67 \mathrm{~km}^{2}$.

The calculated recharge area ranges from 2.67 to $3.38 \mathrm{~km}^{2}$, which correlates far better to the larger of the two proposed hydrogeological recharge areas of the TLV aquifer (Fig. 9), which have areas from $0.80 \mathrm{~km}^{2}$ (minimum area) to $3.39 \mathrm{~km}^{2}$ (maximum area). Regarding the results of the estimated discharge, the larger recharge area, which includes some inflow from the Slatna aquifer, is much more realistic.

\section{CONCLUSIONS}

High-altitude lakes in the Julian Alps are generally considered to be glacial in origin. In the Jezero $v$ Ledvici lake, such interpretation is problematic, as its eastern banks are composed of highly karstified Jurassic limestone. We propose a hydrogeological model, where the lake is part of a karstic aquifer with perched groundwater. The lateral barriers are formed by prominent deflector faults, whereas a vertical barrier is represented by several clay intercalations that occur within the Jurassic bedded limestone there. The specific structure of the area formed a segmented "gutter-shaped" aquifer that we call the Triglav Lakes Valley aquifer. This aquifer collects and distributes water from the north down towards the southern parts of the valley. The Jezero v Ledvicah lake is located inside a segment (tectonic block), which counters the general southward-lowering trend. Therefore, this segment represents a hydrogeological as well as morphological depression in which groundwater accumulates and probably even outcrops as lake water. Specifically, due to a prominent inflow in the northern part of the lake, and an outflow in the south-eastern part of the lake, we propose that the Jezero $\mathrm{v}$ Ledvicah is actually a sub-aerially revealed part of the Triglav Lakes Valley aquifer. The final outflow from the Triglav Lakes Valley aquifer appears at the southern end of the valley, where the Jurassic rocks there finally pinch out. 


\section{ACKNOWLEDGMENTS}

This research was financially supported by the Slovenian Research Agency (research core funding No. P1-0195(B) and No. P1-0011). We thank Miran Udovč, Barbara Bo- har Bobnar, and Mladen Štumergar for their technical support, and reviewers for their constructive comments.

\section{REFERENCES}

ARSO - Slovenian Environment Agency, 2018: ARSO Meteo.- [Online] Available from: http://meteo.arso. gov.si/ [Accesed 15th May 2019].

Boudagher-Fadel, M.K., Rose, E.P.F., Bosence, D.W.J. \& A.R. Lord, 2001: Lower Jurassic foraminifera and calcified microflora from Gibraltar, Western Mediterranean.- Palaeontology, 44, 601-621. DOI 10.1111/1475-4983.00193

Barattolo, F. \& R. Romano, 2005: Shallow carbonate platform bioevents during the Upper Triassic-Lower Jurassic: an evolutive interpretation.- Bollettino della Societa $\bigotimes$ Geologica Italiana, 124, 123-142.

Brancelj, A., 2004: High Mountain Lakes in the Alps.- In: Trilar, T. Cogala, A. \& M. Jeršak (eds.) Nature of Slovenia, The Alps. pp. 63-67.

Brancelj, A., 2015: Vode in življenje v njih.- In: Zorn, M., Smrekar, A., Brancelj, A., Dakskobler, I., Poljanec, A., Peršolja, B., Erhartič, B., Ferk, M., Hrvatin, M, Komac, B. \& D. Ribeiro (eds.) Dolina Triglavskih jezer. (Geografija Slovenije, ISSN 1580-1594, 32), Založba ZRC, pp. 49-58, Ljubljana.

Brancelj, A. \& J. Urbanc, 2000: Karst groundwater connections in the Valley of the seven Triglav lakes. Acta Carsologica, 29, 47-54.

Brenčič, M., 2004: Ground Waters in the Alps.- In: Trilar, T. Cogala, A. \& M. Jeršak (eds.) Nature of Slovenia, The Alps. pp. 51-55.

Brenčič, M. \& P. Vreča, 2016: Hydrogeological and isotope mapping of the karstic River Savica in NW Slovenia.- Environmental Earth Sciences, 75, 651. DOI: 10.1007/s12665-016-5479-7

Buser, S., 1987: Explanatory note to the Basic geological map of SFRJ. 1:100.000, sheet Tolmin in Videm.Zvezni geološki Zavod, pp.103, Beograd.

Buser, S., 1989: Developement of the Dinaric and the Julian Carbonate Platforms and of the intermediate Slovenian Basin (NW Yugoslavia).- Memorie della Societa` Geologica Italiana, 40, 313-320.

Buser, S., 2009: Geological map of Slovenia 1:250,000.Geološki zavod Slovenije, Ljubljana.

Celarc, B. \& T. Kolar-Jurkovšek, 2008: The Carnian Norian basin-platform system of the Martuljek Moun- tain Group (Julian Alps, Slovenia): progradation of the Dachstein carbonate platform.- Geologica Carpathica, 59/3, 211-224.

Celarc, B., Goričan, Š. \& T. Kolar-Jurkovšek, 2013: Middle Triassic carbonate-platform break-up and formation of small-scale halfgrabens (Julian and Kamnik-Savinja Alps, Slovenia).- Facies, 59/3, 583-610. DOI: $10.1007 /$ s10347-012-0326-0

Chiocchini, M., Farinacci, A., Mancinella, A., Molinari, V. \& M. Potetti, 1994: Foraminiferal, dasycladacean and calpionellid biostratigraphy of the Mesozoic carbonates of the Central Apennines (Italy).- In: Biostratigraphy of the Central Italy. Studi Geol. Camerti, Roma, spec. vol. 1994, pp. 9-130.

Čar, J., 2018: Geostructural mapping of karstified limestones.- Geologija, 61/2, 133-162. DOI: 10.5474/ geologija.2018.010

DeWalle, D.R. \& A. Rango, 2008: Principles of snow hydrology.- Cambridge University Press, pp. 410, Cambridge.

Gams, I., 1962: Visokogorska jezera v Sloveniji. Geografski zbornik, 17, 197-261.

Goričan Š., Žibret L., Košir, A., Kukoč, D. \& A. Horvat, 2018: Stratigraphic correlation and structural position of Lower Cretaceous flysch-type deposits in the eastern Southern Alps (NW Slovenia).- International Journal of Earth Sciences, 107/8, 2933-2953. DOI: $10.1007 /$ s00531-018-1636-4

Herlec, U., 2009: Nov genetski tip žlebičev ob visokogorskih jezerih, nastal zaradi pospešenega zakrasevanja s kondenzacijsko vodo.- Geološki zbornik, 20, 40-41.

Herlec, U., Celarc, B. \& M. Mišič, 2009: Pomen identifikacije piroklastitov za korelacijo jurskih plasti Julijskih Alp in Slovenskega jarka.- Geološki zbornik, 20, 48-51.

Hock, R. 2003: Temperature index melt modelling in mountain areas.- Journal of Hydrology, 282, 104115. DOI: 10.1016/S0022-1694(03)00257-9

Hrvatin, M., Zorn, M., Ferk, M., Komac, B. \& B. Erhartič,2015: Relief-. In: Zorn, M., Smrekar, A., Brancelj, A., Dakskobler, I., Poljanec, A., Peršolja, B., Erhar- 
tič, B., Ferk, M., Hrvatin, M, Komac, B. \& D. Ribeiro (eds.) Dolina Triglavskih jezer. (Geografija Slovenije, ISSN 1580-1594, 32), Založba ZRC, pp. 37-47.

Janež, J. 2002: Veliki kraški izviri v zgornjem Posočju = Karst springs in the Upper Soča Valley.- Geologija, $45,2,393-400$.

Jurkovšek, B., 1986: Basic Geological Map of SFRJ 1:100.000, sheet Beljak in Ponteba.- Zvezni geološki zavod, Beograd.

Jurkovšek, B., 1987: Explanatory note to the Basic Geological Map of SFRJ 1:100.000, sheet Beljak in Ponteba.Zvezni geološki zavod, pp. 58, Beograd.

Kastelic, V., Vrabec, M., Cunningham, D. \& A. Gosar, 2008: Neo-Alpine structural evolution and presentday tectonic activity of the eastern Southern Alps: the case of the Ravne Fault, NW Slovenia.- Journal of Structural Geology, 30, 963-975. DOI: 10.1016/j. jsg.2008.03.009

Kunaver, J., 2004: High Mountain Karst in the Slovenian Alps.- In: Trilar, T. Cogala, A. \& M. Jeršak, (eds.) Nature of Slovenia, The Alps. pp. 30-34.

Mancinelli, A., Chiocchini, M., Chiocchini, R.A. \& A. Romano, 2005: Biostratigraphy of Upper Triassic-Lower Jurassic carbonate platform sediments of the central-southern Apennines (Italy).- Rivista Italiana di Paleontologia e Stratigrafia, 111, 271-283. DOI: 10.13130/2039-4942/6314

Muri, G. \& A. Brancelj, 2002: Physical and chemical properties of lake water and ice cover.- In: Brancelj, A. (ed.). High-mountain lakes in the Eastern part of the Julian Alps. Založba ZRC, pp. 91-110, Ljubljana.

Ogorelec, B. \& S. Buser, 1996: Dachstein limestone from Krn in Julian Alps (Slovenia) $=$ Razvoj dachsteinskega apnenca na Krnu v Julijskih Alpah.- Geologija, 39, 133-157. DOI: doi:10.5474/geologija.1996.006

Petrič, M., 2004: Alpine karst waters in Slovenia.- Acta Carsologica, 33/1, 11-24.

Placer, L., 1999: Contribution to the macrotectonic subdivision of the border region between Southern Alps and External Dinarides.- Geologija, 41, 223255. DOI: $10.5474 /$ geologija. 1998.013

Placer, L., 2008: Principles of the tectonic subdivision of Slovenia.- Geologija, 51, 205-217. DOI: 10.5474/geologija.2008.021

Placer, L., 2016: Geotectonic setting of Slovenia.- In: Novak, M. \& N. Rman, (eds): Geological atlas of Slovenia. Geološki zavod Slovenije, pp. 14-15, Ljubljana.

Pomoni-Papaioannou, F. \& V. Kostopoulou, 2008: Microfacies and cycle stacking in Liassic peritidal carbonate platform strata, Gavrovo-Tripolitza platform, Peloponnesus, Greece.- Facies, 54, 417-431. DOI: 10.1007/s10347-008-0142-8

Rango, A. \& J. Martinec, 1995: Revisiting the degree- day method for snowmelt computations.- Water Resources Bulletin, American water resources association, 31, 4, 657-669. DOI: 10.1111/j.17521688.1995.tb03392.x

Šmuc, A., 2005: Jurassic and Cretaceous stratigraphy and sedimentary evolution of the Julian Alps, NW Slovenia.- Založba ZRC, pp. 98, Ljubljana.

Šmuc, A., 2015: Geologija.- In Zorn, M. et al.(eds.) Dolina Triglavskih jezer. (Geografija Slovenije, ISSN 1580-1594, 32), Založba ZRC, pp. 26-35.

Šmuc, A. \& B. Rožič, 2009: Tectonic geomorphology of the Triglav Lakes Valley (easternmost Southern Alps, NW Slovenia).- Geomorphology 103, 4, 597604. DOI: 10.1016/j.geomorph.2008.08.005

Šmuc, A. \& B. Rožič, 2010: The Jurassic Prehodavci Formation of the Julian Alps: Easternmost outcrops of Rosso Ammonitico in the Southern Alps (NW Slovenia).- Swiss Journal of Geosciences, 103, 241-255. DOI: $10.1007 /$ s00015-010-0015-3

Šušteršič, F., 2006: Relationships between deflector faults, collapse dolines and collector channel formation: some examples from Slovenia.- International Journal of Speleology, 35, 1-12. DOI: 10.5038/1827806X.35.1.1

Šušteršič, F., Čar, J. \& S. Šebela, 2001: Zbirni kanali in zaporni prelomi - Collector channels and deflector faults (In Slovene, English Summary).- Naše jame, $43,8-22$.

Trišič, N., Bat, M., Polajnar, J. \& J. Pristov, 1997: Water balance investigations in the Bohinj region.- In: Kranjc, A. (ed), Tracer Hydrology. pp. 295-298.

Tunaboylu, B.C., Altiner, D., Isintek, I. \& D. Demirci, 2014: Foraminiferal biostratigraphy and sequence stratigraphy of peritidal carbonates at the Triassic-Jurassic boundary (Karaburun Peninsula, Western Turkey).- Journal of Asian Earth Sciences, 90, 6176. DOI: $10.1016 /$ j.jseaes.2014.04.015

Urbanc, J. \& A. Brancelj, 1999: Tracing experiment in lake Jezero v Ledvici, valley Triglavska jezera.- Geologija, 42, 207-214.

Urbanc, J. \& A. Brancelj, 2002: Hydrological connections between some lakes in the Triglav lakes valley.- In: Brancelj, A. (ed.). High-mountain lakes in the Eastern part of the Julian Alps. Založba ZRC, pp. 77-90.

Vidmar, I. 2015: Prispevek snežne in dežne komponente $k$ iztoku iz vodonosnika reke Savice : magistrsko delo $=$ Contribution of snow and rain component to discharge from the Savica River aquifer : master's thesis.University of Ljubljana, Faculty of Natural Sciences and Engineering, Department of Geology, pp. 65.

Vidmar, I. \& M. Brenčič, 2018: Determination of a highaltitude karstic aquifer recharge conditions: case 
study of Savica River aquifer in NW Slovenia.- Geophysical Research Abstracts, 20, 7654.

Zini, L., Casagrande, G, Calligaris, C., Cucchi, F., Manca, P., Treu, F., Zavagno, E. \& S. Biolchi, 2015: The Karst Hydrostructure of the Mount Canin (Julian
Alps, Italy and Slovenia).- In: Andreo, B., Carrasco, F., Durán, J., Jiménez, P., \& J. LaMoreaux, (eds.) Hydrogeological and Environmental Investigations in Karst Systems. Environmental Earth Sciences, vol 1. Springer, 219-226, Berlin, Heidelberg. 